\title{
Airline Deregulation and Airport Regulation
}

This Note examines the impact of the 1977 deregulation of airlines on the regulation of the market for airport services. The Note concludes that: (1) this "regulatory interaction"1 has merely shifted a large part of the administrative regulatory burden associated with the regulation of air transportation from airlines to airports; (2) airports cannot efficiently manage this burden under the current regulatory regime; (3) existing federal regulations on user fees and their current judicial interpretation may prevent airports from developing an effective and efficient solution to the problems created by airline deregulation. The Note suggests changes in the regulation of airports and airlines which would increase the benefits of airline deregulation. In particular, the Note proposes allocating access to airports by auction, subjecting the airport terminal subleasing policies of airlines to a heightened antitrust scrutiny, foreclosing the ability of certain airlines to veto plans to expand airport terminal capacity, and requiring new entrant airlines to bear the full cost of their entry.

\section{Federal Regulation of Air Transportation}

In October 1978 Congress enacted the Airline Deregulation Act of 1978. ${ }^{2}$ Before deregulation, the Civil Aeronautics Board (CAB) comprehensively regulated virtually every "business" decision of interstate com-

1. Regulatory interaction-the impact of regulation (or deregulation) of one area of an industry on other regulated areas-occurs in closely connected markets. It may occur because, as in the airline industry, two inputs (airline services and airport services) are required to produce a single output (air transportation). This particular type of regulatory interaction is also important in the telecommunications industry, where the deregulation of the long-distance market created the need to regulate access to local telephone systems. Such interaction also occurs where an industry produces joint outputs which are both regulated, e.g., the electric utility industry, which produces both electricity and pollution, or where regulated products are partial substitutes, e.g., checking accounts at commercial and savings banks and money market mutual fund accounts.

2. Airline Deregulation Act of 1978, Pub. L. No. 95-504, 92 Stat. 1705 (codified in scattered sections of 49 U.S.C.). 
mercial air carriers: ${ }^{3}$ entry and exit from individual city-pair markets, ${ }^{4}$ air fares, ${ }^{5}$ methods of competition, ${ }^{6}$ mergers and acquisitions, ${ }^{7}$ and intercarrier agreements. ${ }^{8}$ Under the Airline Deregulation Act, the authority of the CAB to regulate airlines is gradually disappearing. ${ }^{\circ}$

Federal regulation of other areas of the air-transport industry remains intact. In particular, the Federal Aviation Administration (FAA) ${ }^{10}$ continues to have regulatory jurisdiction over airway support services and aviation safety. ${ }^{11}$ The intervention of the FAA in the day-to-day operation of airports, ${ }^{12}$ however, has always been much more limited than the CAB's regulation of commercial airlines. ${ }^{13}$

3. There was, however, some deregulation by the CAB itself prior to 1978. See Bailey, Deregulation and Regulatory Reform of U.S. Air-Transportation Polig, in Regulated INDUSTRIES AND Public Enterprise 29, 30-35 (1980); Civil Aeronautics Board, Antitrust Policy for the Aviation Industry 3-5 (1982) [hereinafter cited as CAB ANTITRust Report]. The CAB was formed in 1940 as an independent regulatory agency with the explicit responsibility for promoting and regulating the air-transport industry. See D. Wyckoff \& D. MaISTER, The Domestic AIRLINE INDUSTRY Xiv (1977).

4. Under $\mathrm{CAB}$ regulation, an airline had to obtain a certificate of "public convenience and necessity" from the CAB before it could initiate service on any route. 49 U.S.C. $\$ 1371$ (a), (d)(1) (1976). The abandonment of any route for which a certificate had been issued also required CAB approval. Id. $\$ 1371(j)$. The CAB's administration of these statutes effectively prevented entry into the airline industry. For example, although the CAB received 79 applications between 1950 and 1974 from companies wishing to enter the domestic airline industry, it granted none of these applications. S. Breyer, Regulation AND ITS Reform 205 (1982). Between 1969 and 1974, the CAB granted fewer than four percent of all applications by existing airlines for new routes. Id.

5. 49 U.S.C. $\$ 1373$ (1976). For a discussion of CAB price regulation, see S. BREYER, supra note 4 , at $210-12$.

6. 49 U.S.C. $\S 1381$ (1976). Examples of the airlines' methods of competition include scheduling frequency and fare discounting.

7. Id. $\S 1378$.

8. Id. $\S 1382$. Agreements among carriers related to virtually every aspect of the airline business, including the establishment of fares and the character of service. Id. $\S 1382(\mathrm{a})$. Agreements approved by the $\mathrm{CAB}$ were immune from the antitrust laws. Id. $\S 1384$. For a discussion of the difficulty of enforcing these agreements and their effect on airline profits, see S. BREYER, supra note 4, at 218-19.

9. The CAB's authority over routes ended on December 31, 1981. 49 U.S.C. $\$ 1551$ (a)(1)(A) (Supp. V 1981). Its authority to declare fares unlawful expired on January 1, 1983. Id. $\S 1551(\mathrm{a})(2)(\mathrm{A})$. The $\mathrm{CAB}$ itself is scheduled to go out of existence on January 1, 1985.Id. $\S$ $1551(\mathrm{a})(4)$.

10. The FAA was created as an independent agency in 1958. See Federal Aviation Act of 1958, Pub. L. No. 85-726, § 301, 72 Stat. 731, 744. It became part of the Department of Transportation with the Department's formation in 1966. See Department of Transportation Act, Pub. L. No. 89$670, \S 3(\mathrm{e}), 80$ Stat. $931,932(1960)$.

11. See 49 U.S.C.A. \& 106 (g) (West Supp. 1983).

12. The FAA is primarily involved in the daily operation of most civil airports through its ownership and operation of air traffic control equipment. See J. WArford, Public Policy Toward GeNERAL. Aviation 113 (1971). The agency also administers the granting of federal subsidies to airports for the construction of runways, taxiways, and certain types of lighting equipment. Sep 14 C.F.R. $\S 152$ (1983); see also p. 321. For a discussion of the history of federal subsidization of airport development, see R. Eckert, Airports and Congestion: A Problem of Mísplaced Subsidies 3-12 (1972); J. WARFORD, supra, at 112-21.

13. The Airline Deregulation Act of 1978, Pub. L. No. 95-504, $\S 105,92$ Stat. 1705, 1708 (1978) (codified at 49 U.S.C. $\$ 1305$ (Supp. V 1981)), preempts state and local control over any aspect of an air carrier's "rates, routes, or services," 49 U.S.C. $\$ 1305$ (a)(1), but also declares that nothing in the preemption provision "limit[s] the authority of any State or political subdivision thereof . . . as the owner or operator of an airport . . . to exercise its proprietary powers and rights." Id. 
The federal intervention of greatest importance for the regulatory interaction that this Note examines is the oversight of airport user fees-the charges that an airplane must pay to use an airport. This intervention takes two forms. First, an airport must agree to regulation of user fees to receive federal construction subsidies. The FAA administers the "grant agreement" for these subsidies. ${ }^{14}$ The grant agreement must provide that the airport will be "available for public use on fair and reasonable terms and without unjust discrimination,"15 and that all revenues generated by a public airport will be spent on the capital or operating costs of the airport. ${ }^{16}$ Second, all airports, whether or not they receive federal subsidies, must keep their user fees to a "reasonable" level. ${ }^{17}$

It is unclear exactly what constraints these requirements impose on an airport's discretion to set its user fees, especially given the general policy against federal intervention into airports' proprietary affairs. ${ }^{18}$ Nevertheless, typical airport pricing policies, the legislative history of the governing statute, and litigation over airport user fees and taxes provide some guidance as to what constitutes a "reasonable" fee.

$\S 1305(b)(1)$. In City of Burbank v. Lockheed Air Terminal, Inc., 411 U.S. 624 (1973), the Court held that the broad powers given by Congress to the FAA preempted states from exercising their police power to regulate airport operations. Id. at 640 (striking down municipal ordinance banning late-night jet activity). However, the Court also stated, "We do not consider here what limits, if any, apply to a municipality as a proprietor." Id. at 635-36 n.14; $f$. British Airways Bd. v. Port Auth., 564 F.2d 1002, 1010-13 (2d Cir. 1977) (striking down local ban on Concorde flights as unreasonable, but recognizing authority of airport proprietor to protect local population from noise). See generally J. WARFORD, supra note 12, at 79 (FAA intervention in most airport policies would be unwarranted intrusion into state and local affairs). The exceptions to this general rule of limited involvement are Washington's National and Dulles Airports, which are owned by the federal government and operated by the FAA.

14. See 14 C.F.R. $\S 152$ (1983) (regulations governing FAA administration of subsidies).

15. 49 U.S.C. $\S 1718(a)(1)$ (1976) (current version at 49 U.S.C.A. $\S 2210(a)(1)$ (West Supp. 1983)); see also Levine, Landing Fees and the Airport Congestion Problem, 12 J. L. \& EcoN. 79, 84-85 (1969) ("The extent to which this provision limits the pricing freedom of the airport operator has not been settled.").

16. 49 U.S.C.A. $§ 2210(a)(12)$ (West Supp. 1983). Airports that are part of a unified port authority may, however, use their revenues to service the general debt obligations of the port authority if bond covenants in previously issued debt obligations or the port authority's governing statutes so require. Id.

17. 49 U.S.C. $\S 1513(b)$ (1976). Section 1513(a) prohibits any state or local "tax, fee, head charge, or other charge, directly or indirectly, on persons traveling in air commerce . . . or on the sale of air transportation or on the gross receipts derived therefrom." Id. $\S 1513(\mathrm{a})$. Because the scope of this section would apparently prohibit any state or local government from levying any taxes or fees on aircraft operators, the statute provides that "[n]othing in this section shall prohibit . . a an airport from levying or collecting reasonable rental charges, landing fees, and other service charges from aircraft operations for the use of airport facilities." Id. $\S 1513(\mathrm{~b})$. Airport and Airway Improvement Act of 1982, Pub. L. No. 97-248, § 532, 96 Stat. 671, 701, added a new subsection to $\S 1513$ which restricted the ability of states to tax air carrier property. 49 U.S.C.A. $\S 1513$ (d) (West Supp. 1983).

18. See supra note 13. 


\section{Federal Regulation of Airport User Fees}

The economics of the market for airport services is a useful starting point in determining what a "reasonable" fee is. Major airports are generally natural monopolies ${ }^{19}$ since the construction of a major airport involves large sunk costs. ${ }^{20}$ If airport fees were unrestricted, an airport would be able to impose fees and taxes reflecting its monopoly power. ${ }^{21} \mathrm{~A}$ local governmental authority, as owner of the airport, could thereby unreasonably inhibit the flow of interstate commerce. ${ }^{22}$ It is not surprising, then, that airports are subject to a federal statute-49 U.S.C. § 1513-that restricts their fees to a "reasonable" level. ${ }^{23}$

19. For a general discussion of monopolies, see J. Hirshleifer, Price Theory and ApplicaTIONS 334-48 (2d ed. 1980). The term "natural monopoly" refers to a situation where the cost per unit of production (average cost) falls throughout the relevant range of production. Such economies of scale imply that one firm can supply the entire market at a lower total cost than can two or more firms. See id. at 348-49.

20. Large sunk costs tend to create natural monopolies because the average cost of production will generally decrease as fixed costs are spread over a larger number of units as production is increased. For this reason, the minimum efficient scale of an airport-the lowest level of output at which average cost is at a minimum-tends to be large relative to the demand for air transportation in most urban areas. The natural monopoly character of an airport, however, probably holds true only for the actual runway and taxiway facilities at an airport. Individual airlines could be responsible for building their own terminal facilities, for which economies of scale seem more limited. In fact, this arrangement is used at some airports, including Kennedy Airport in New York City. See AIRPORT ACCESS TASK FORCE, REPORT AND RECOMMENDATIONS OF THE AIRPORT ACCESS TASK ForCe 50 (presented to Congress on March 10,1982) (study conducted pursuant to Airport and Airway Improvement Act of 1982, Pub. L. No. 97-248, § 527, 96 Stat. 671, 698). Since airports are used for connecting flights as well as for beginning and ending flights, there are also economies of scale associated with having several airlines at one runway facility.

21. These fees and taxes are the prices charged to the airlines and general aviation users. As a natural monopoly, the airport could charge a higher price for its services than could be justified in terms of cost recovery. See supra note 19 . Even if an airport authority were able to charge monopoly prices, however, it might prefer not to do so. Imposing monopoly prices would decrease the use of the airport and the concomitant commercial activity that such use generates in the surrounding municipality. A decrease in such commercial activity may reduce tax revenue by more than the additional revenue generated by monopoly prices.

22. Of course, any fee charged by a local government for a particular service that involves interstate activity will "inhibit" the flow of interstate commerce. Hence, such inquiries must always focus on the unreasonableness of a particular fee. See Evansville-Vanderburgh Airport Auth. Dist. v. Delta Airlines, 405 U.S. 707, 716-17 (1972) (tax may not be "excessive in comparison with the governmental benefit conferred").

The existence of a natural monopoly also raises difficult problems of allocative efficiency. Efficient resource allocation generally requires setting the price of a product equal to the additional, or "marginal," cost of producing another unit of that product. See J. HirshleIfER, supra note 19, at 526-29. However, since the construction of airports requires large sunk costs, the marginal cost of a takeoff or landing will always be less than its average cost. See id. at 349 . Therefore, pricing exclusively according to short-run marginal cost would not generate enough revenue to pay the airport's capital and operating costs and thus would require outside subsidization of airport operations. For a discussion of efficient pricing schemes in this situation, see J. WARFORD, supra note 12 , at 29-37, 156-57.

23. 49 U.S.C. $\S 1513(b)$ (1976). Airports that accept federal construction subsidies are subject to additional pricing constraints. See supra p. 321 . The legislative history of 49 U.S.C.A. $\S 1513$ indicates that its purpose was to prevent taxes and fees which "inhibit the flow of interstate commerce." S. ReP. No. 12, 93d Cong., 1st Sess. 4 (1973), reprinted in 1973 U.S. Code ConG. \& AD. News 1434, 1435. 
Although "reasonable" is not defined in section 1513, the statute's legislative history does give some guidance in interpreting the term. Section 1513 was enacted in response to the Supreme Court's decision in Evansville-Vanderburgh Airport Authority District v. Delta Airlines, ${ }^{24}$ in which the Court upheld "reasonable" passenger head taxes imposed by local governments for "aviation-related purposes."2s After EvansvilleVanderburgh, many public airports began collecting head taxes. ${ }^{28}$ Congress feared that such taxation by state and local governments would create a "potentially chaotic burden" on airline services. ${ }^{27}$ Congress was also concerned because "the [Evansville-Vanderburgh] decision did not sufficiently define the ruling as [to] what constitutes a reasonable charge, or [as to] just how far a state or municipality could go in levying head taxes." ${ }^{28}$ Finally, Congress worried that state and local governments might use head taxes to gain "financial windfalls" and use the revenue for purposes unrelated to airport development. ${ }^{29}$

In response, Congress enacted section 1513, which prohibited airport head taxes $^{30}$ and restricted all airport fees to a "reasonable" level. ${ }^{31}$ It appears that the overall purpose of this legislation was to prevent revenues from airport user fees from exceeding airport operational and capital costs. $^{32}$ Thus, under section 1513, user fees which provide revenue greater

24. 405 U.S. 707 (1972).

25. Sep S. Rep. No. 12, 93d Cong., 1st Sess. 17 (1973), reprinted in 1973 U.S. Code Cong. \& AD. NEws 1434, 1446. A head tax is a tax on each enplaning and/or deplaning passenger.

26. Id. at 17, 21, reprinted in 1973 U.S. Code Cong. \& AD. News 1434, 1446, 1450. Philadelphia, for example, imposed a two-dollar head tax on enplaning and deplaning passengers. Id.

27. Id. at 17, reprinted in 1973 U.S. Code CoNG. \& AD. News at 1446.

28. Id.

29. Id. The legislative history stated, "Quite clearly, if head taxes are to be used for non-aviation purposes, or for programs which don't benefit the airport system where it is [sic] collected, such taxes are not equitable." Id. at 22, reprinted in 1973 U.S. Code Cong. \& AD. News at 1451.

Some of this congressional concern with the Evanstille-Vanderburgh decision may have been misplaced. In its decision, the Supreme Court stated that "a charge designed only to make the user of state-provided facilities pay a reasonable fee to help defray the costs of their construction and maintenance may constitutionally be imposed on interstate and domestic users alike." EvansvilleVanderburgh Airport Auth. Dist. v. Delta Airlines, 405 U.S. 707, 714 (1972). The Court stated further that "so long as the funds received by local authorities . . . are not shown to exceed their airport costs, it is immaterial whether those funds are expressly earmarked for airport use." Id. at 720.

30. 49 U.S.C. $\S 1513($ a) (1976).

31. Id. § $1513(\mathrm{~b})$.

32. A balancing of revenue and costs also seemed necessary under Evanswille-Vanderburgh: "[A] charge designed only to make the user of state-provided facilities pay a reasonable fee to help defray the costs of their construction and maintenance may constitutionally be imposed on interstate and domestic users alike." Evansville-Vanderburgh Airport Auth. Dist. v. Delta Airlines, 405 U.S. 707, 714 (1972). Moreover, the grant agreements with airports accepting federal subsidies must provide that the airport will maintain a fee structure to "make the airport as self-sustaining as possible under the circumstances" but that no federal subsidies will be "included in the rate base in establishing fees, rates, and charges for users of that airport." 49 U.S.C. $§ 1718(a)(8)(1976)$ (current version at 49 U.S.C.A. $§ 2210($ a)(9) (West Supp. 1983)). 
than that needed to recover the cost of maintaining airport facilities and debt service charges are unreasonable. ${ }^{33}$

The "cost-recovery" interpretation of section 1513 is consistent with the general pricing policies employed by most airports. ${ }^{34}$ The legislation, however, does not specify how to distribute the burden of recovering airport costs among airlines, general aviation users, airline passengers, and airport concessionaires. ${ }^{35}$ Thus, the allocation of costs among the various users of the airport is apparently within the discretion of the airport operator. ${ }^{36}$

The distribution of airport costs varies with the accounting system used by a particular airport. Under the accounting system used by most airports, the entire airport is treated as one "cost center." erator generally first maximizes revenue from ancillary airport operations-primarily terminal concessions ${ }^{38}$ and parking facilities. The airport

33. Both the FAA and private parties can presumably enforce $\S 1513$. Although $\S 1513$ does not explicitly grant a private right of action, the courts have assumed without comment that such a right of action exists. Usually the private party attempting to enforce $\$ 1513$ is an airline. See, e.g., American Airlines v. City of Philadelphia, 427 F. Supp. 995, 996 (E.D. Pa. 1977). The wisdom of this assumption is doubiful. It places a federal district court judge in a position similar to that of a public utility commission. See Indianapolis Airport Auth. v. American Airlines, 17 Av. Cas. (CCH) Tा 17,513 (S.D. Ind. Sept. 30, 1982) (appropriate accounting method for airport and whether an additional runway was needed). There is no reason to assume that judges are competent to perform such a function. In addition, the legislative history of $\S 1513$ indicates that the statute was passed at least in part because of congressional concerns that the Supreme Court's definition of "reasonable" in Ev'anszille-Vanderburgh was not sufficiently precise. See supra p. 323. A more appropriate remedy would entail some type of regulatory review by the FAA.

34. See Levine, supra note 15, at 86-87; Lowell, How to Make Your Airport Financially SelfSufficient, in Airport Economic Planning 317 (G. Howard ed. 1974).

35. Restricting overall airport fees to a "reasonable" level does not necessarily imply any congressional intent to dictate how or from whom airport costs should be recovered. In fact, the sources of revenue vary enormously among different airports. See Bauml, Airport Revenues and Expenses, in Airport ECONomic Planning 365-91 (G. Howard ed. 1974); J. WARford, supra note 12, at 128. The reliance on different sources of revenue is due in part to differences among airports in the number of flights to and from the airport or in the amount of concession space at the airport. It also reflects differences in the types of charges made by a particular airport. For example, an airport may impose "fuel flowage fees" rather than landing fees. See Bauml, supra, at 377. Finally, the reliance on different sources of revenue reflects differences in the accounting systems used by airports. See infra pp. 324-25.

36. But see Indianapolis Airport Auth. v. American Airlines, 17 Av. Cas. (CCH) II 17,513 (S.D. Ind. Sept. 30, 1982) (holding, on basis of $\S 1513$, that proposed accounting change would impose unreasonable fees on airlines and should therefore be enjoined).

37. See Levine, supra note 15 , at 88-89.

38. Airport terminal concessions are generally allocated by competitive bidding. This enables the airport operator to capture at least part of any monopoly profits arising from the locational advantages of being in the airport terminal. See id. at 100; Mooney, Developing Concession Revenues at Airports, in AirPort Economic Planning 503, 505 (G. Howard ed. 1974). The general use of this system implies that the rule against an airport operator's exploiting its monopoly power extends only to landing fees (including landing fees in the form of taxes on airplane fuel) and passenger head taxes. Such airport actions, however, may now be susceptible to attack under the antitrust laws after the Supreme Court's decision in Community Communications Co. v. City of Boulder, 455 U.S. 40 (1982) ("state action" exemption does not prohibit antitrust scrutiny of municipality). For a discussion of several cases involving municipalities, see Dolley \& Barker, Airport Antitrust Regulation, 14 URB. LAw. 673, 673-77 (1982). Exempting airports from the antitrust laws may, in some circumstances, be 
then assesses landing fees only to the extent necessary to recover the operating and maintenance costs for the entire airport. Airlines are thus only a "last resort" source of revenue. ${ }^{39}$

An alternative accounting system, the "multiple cash register" technique, breaks down the airport into various cost centers, only some of which produce revenues. ${ }^{40}$ The costs of non-revenue-producing areas are allocated to revenue-producing areas on some "equitable basis."41 The goal of this method is "to make each revenue producing area pay its own way." $" 42$

Under either of the above accounting methods, airport landing fees are based on "cost recovery." In the case of multiple cost centers, however, the airlines will generally be required to pay a larger proportion of total airport costs, because under this accounting system the costs of building and maintaining the landing and gate areas of the airport are not subsidized by revenues from other parts of the airport. ${ }^{43}$ Nevertheless, in both cases the airport's services are priced to generate just enough revenue to cover the capital and operating costs of the airport.

\section{SLot-Constrained Airports}

Given statutory restrictions on their landing fees, airports cannot raise their prices to charge whatever the market will bear. This system works smoothly only if the quantity of airport services demanded at a costrecovery price is less than the airport's capacity. ${ }^{44}$ If the capacity of a

justified on the grounds that if such monopoly rents, due to the locational advantages of being in the airport, are not captured by the airport, they will be captured by the airport concessionaire. An airport operator could prevent airport concessionaires from capturing such rents by regulating the prices of goods and services sold at the airport. This type of regulation, however, would probably create a greater administrative burden than most airport operators would be willing to assume. But in other cases, an airport proprietor could create and capture monopoly rents by selling exclusive franchises for certain airport concessions. Such practices should not be exempt from the antitrust laws.

39. See Levine, supra note 15 , at 89 . Under this accounting system, sometimes called the "single cash register" method, an airport's ancillary services may subsidize the landing area of the airport.

40. Examples of cost centers that are essential to the operation of the airport but that do not produce revenues include airport roadways, passenger waiting areas and bathrooms, and airport security services.

41. See Lowell, supra note 34, at 319. Lowell states that this allocation may be based on "direct labor hours, equipment hours, revenue dollar, expense dollar or a combination of these or other bases." Id. The court in Indianapolis Airport Auth. v. American Airlines, 17 Av. Cas. (CCH) If 17,513 (S.D. Ind. Sept. 30, 1982), rejected an accounting plan that allocated costs based on a combination of "management analysis" (presumably based on the kind of factors listed above) and "revenue acres" (an allocation based on the number of acres in each revenue-producing area).

42. Lowell, supra note 34 , at 319 .

43. Airlines can thus be expected to resist a change of accounting systems by an airport from the "single cash register" method to a "multiple cash register" technique. This was the basis of the litigation in Indianapolis Airport Auth. v. American Airlines, 17 Av. Cas. (CCH) I 17,513 (S.D. Ind. Sept. 30, 1982). See supra notes $36 \& 41$.

44. Airports consist of three subsystems: (1) the "airfield," composed of the airport's available airspace, runways, taxiways, and aircraft fuel and maintenance services; (2) the terminal, through 
particular airport is not sufficient to meet the demand for that airport's services at "reasonable" fees, however, the situation becomes considerably more complex.

\section{A. Restricted User Fees and Congested Airports}

One response to a shortage of airport capacity is to expand the airport. ${ }^{45}$ At some airports, however, such expansion is simply not possible, either because of a lack of space for additional runways or because of local restrictions on the amount of noise that can be produced by the airplanes using the facility. ${ }^{46}$ If an airport cannot expand because of a shortage of runway capacity, the short-run effect will be congestion. ${ }^{47}$

In the late 1960 's, congestion became a problem at several large metropolitan airports. ${ }^{48}$ Officials from the affected airports, the $\mathrm{CAB}$, and the FAA attacked the problem through a variety of measures. Airport officials in New York Gity took action first and implemented the only measure that relied on price incentives-an increase in peak-hour takeoff and landing fees for smaller planes at all New York City metropolitan area airports. ${ }^{49}$ The CAB attempted to reduce congestion at airports in New York

which passengers enplane and deplane; and (3) the ground transportation system, through which passengers arrive at and depart from the airport. See AIRPORT Access TASK Force, supra note 20, at 49. An airport's total capacity is limited to the lowest capacity of these three subsystems. This section focuses on constraints created by airfield capacity, including restrictions due to noise and pollution. The next section discusses the problems associated with terminal capacity constraints. Although a recent survey of 33 airports indicated that groundside congestion adversely affected total airport capacity in 11 cases, see id. at 112 , this problem is not examined further here because it is not directly related to either airline deregulation or air carrier behavior. For an analysis of groundside constraints, see id. at 111-21.

45. Expansion may not be appropriate where landing fees are subsidized by ancillary airport activities and by federal, state, and local grants. In these cases, landing fees do not reflect the full longrun marginal costs of supplying airport services, and it may be inefficient to expand an airport to meet a demand which stems from purchases at a price below the true social cost of the resources sacrificed to supply airport services. For a discussion of the magnitude of this cross-subsidization and direct subsidization, see J. WARFORD, supra note 12, at 111-34.

46. Noise is already a serious problem at many airports and is expected to get worse in the near term, although the introduction of quieter airplanes may alleviate the problem in the future. See AIRPORT ACCESS TASK FORCE, supra note 20, at 17. During the past 10 years, additional noiserelated constraints were imposed at 19 of the 35 largest civil airports, and noise concerns inhibited the expansion of 12 of these airports. Id.

47. Congestion occurs when too many users try to use a particular facility at the same time, resulting in queuing and delay. Congestion at an airfort, as on a freeway, develops in part because each user considers only his own average expected delay when deciding whether or not to use the facility in question. The user ignores the additional delay which his use imposes on all other users since he does not bear the cost of these additional delays. Because of this "externality," more than a socially optimal amount of congestion tends to result. See R. ECKERT, supra note 12, at 23; Levine, supra note 15, at 91; see also R. ECKERT, supra note 12, at 38 (discussing CAB policies to reduce congestion).

48. At Washington National, New York, and Chicago, planes were queued on the ground or "stacked" in the air for up to two hours. See R. EcKerT, supra note 12, at 1.

49. Id. at $28-29$. The fee increased from $\$ 5$ to $\$ 25$ and applied to planes seating fewer than 25 persons. The increase substantially reduced the number of small planes using these airports during 
and elsewhere by requiring new carriers on congested routes to use "satellite" airports and by sponsoring agreements among the airlines to reduce scheduling competition..$^{\text {s0 }}$ Finally, the FAA restricted the hourly number of takeoff and landing "slots" available at five congested airports. ${ }^{.1}$

\section{B. The FAA's Slot System}

Under the FAA's restrictions, the slots at a slot-constrained airport are allocated first among the various classes of users of the airport. ${ }^{\mathbf{B 2}}$ The slots available to each class are then distributed among the members of each group. For commercial carriers, the slots are allocated by bargaining among the airlines in meetings of a "scheduling committee." Although these measures have been partially successful at eliminating airport congestion, it is unlikely that they have either produced the optimal amount of use or reduced congestion efficiently. ${ }^{54}$

The deregulation of the airline industry has exacerbated the problem of allocating slots at slot-constrained airports. ${ }^{55}$ Before deregulation, the

peak use hours. See id. at 28. The increase was upheld in Aircraft Owners and Pilots Ass'n v. Port Auth., 305 F. Supp. 93 (E.D.N.Y. 1969).

50. See R. ECKERT, supra note 12, at 38. CAB-sponsored agreements among airlines receive antitrust immunity. See 49 U.S.C. $\S 1384$ (1976). For an explanation of why scheduling competition is a problem, see supra note 47.

51. This was done at the three airports in the New York City area (Kennedy, LaGuardia, and Newark), Chicago's O'Hare Airport, and Washington's National Airport. See R. EcKERT, supra note 12 , at 34 . The FAA has the authority to impose such restrictions. 49 U.S.C. $\S 1348$ (1976); see also 14 C.F.R. $\$ 93.123$ (1983) (designating slot-constrained airports). Newark Airport is no longer subject to slot restrictions, and the FAA is apparently contemplating removing these restrictions at O'Hare, LaGuardia, and Kennedy Airports. See AIRPORT ACCESS TASK ForCE, supra note 20, at 1. This view, however, has been attacked as being unrealistic. Id. at 38 . In any case, airport access would probably still be constrained by limited terminal capacity at these airports. See infra note 86 . In addition, a recent FAA study projects that 35 airports, including a number of major "hub" airports, will become congested by 1990 . See CAB ANTrTRUST REPORT, supra note 3, at 74 .

52. There are three classes of users: commercial airlines, air taxis, and general aviation. See $R$. ECKERT, supra note 12 , at 34 . Reducing congestion has been accomplished primarily by reducing general aviation use. $I d$. at 35 .

53. Id. at 36-37. For a description of this system of allocating commercial landing slots at slotconstrained airports, see Grether, Isaac \& Plott, The Allocation of Landing Rights by Unanimity Among Compelitors, 71 AM. ECON. Rev. PAPERS \& PROC. 166 (1981). If this non-price rationing system fails to produce an agreement, the FAA can temporarily impose an allocation at a particular airport based on one of four possible systems: (1) a lottery; (2) an auction; (3) grandfathering of slots according to historical pattern; or (4) an administrative process of reviewing applications and applying some formula. Id. at 168. Such a failure occurred at Washington's National Airport in the fall of 1980 when the slot committee refused to grant the slot request of New York Air, a new entrant into the airline industry. See CAB ANTITRUST REPORT, supra note 3, at 77 n.2. The FAA granted New York Air its slot request. Id. at 78. For a description of the bargaining positions of the various participants, see infra note 63.

54. Sep R. ECKERT, supra note 12, at 33-41. Reducing congestion efficiently requires eliminating the lowest-value users first. For this reason, the great reduction in general aviation users was probably efficient, particularly in light of the externality problems involved in the creation of congestion. Sep supra note 47.

55. The 1981 strike by the Professional Air Traffic Controller's Organization (PATCO) also exacerbated the problem of allocating slots because the PATCO strike reduced air traffic capacity at 
scheduling committees faced no demand for slots from new entrants because the $\mathrm{CAB}$ prevented new entry into the airline industry. ${ }^{56}$ In addition, any increases in the demand for slots from existing airlines were mitigated by the necessity of obtaining CAB approval before initiating service on any route. ${ }^{57}$ The deregulation of the airline industry, however, has increased the demand for scarce slots, both from airlines with existing landing rights and from new entrants. Accordingly, designing an efficient non-price rationing system for the allocation of slots at individual airports has become a more difficult regulatory problem. ${ }^{58}$

An analysis of the interaction between the scarcity of slots at slotconstrained airports and the market for air transportation services shows how a scarcity of slots should lead to higher air fares and greater profits on routes which involve at least one slot-constrained airport, and hence, why deregulation should increase the demand for slots. ${ }^{58}$ The excess demand $^{60}$ for slots at a slot-constrained airport is, of course, created by the demand of passengers for flights to or from the particular airport in question. An unsatisfied demand of passengers for flights to or from a slot-

major airports. In response to the PATCO strike, the FAA imposed temporary slot constraints at 22 airports (including those already slot-constrained). See 46 Fed. Reg. 44,424 (1981). The FAA initially allocated the reduced number of slots at these airports in proportion to each airline's pre-strike schedule. Id. As the capacity of the air traffic control system has expanded following the initial reduction caused by the strike, the FAA has allocated new slots by lottery, although it has given some priority to new entrants. See 47 Fed. Reg. 7816 (1982). Since this allocation does not depend upon an airline's willingness to purchase slots, it is subject to the same criticisms as the scheduling-committee system of allocating slots. See infra pp. 329-31.

56. Between 1950 and 1974 , the CAB received 79 applications from companies seeking to enter the domestic airline industry but granted none of these requests. S. BREYER, supra note 4, at 205.

57. The $\mathrm{CAB}$ effectively prevented any increase in the demand for slots from existing airlines. "Between 1938 and 1977, the CAB permitted no entry into markets that already had two or more carriers." Bailey, supra note 3, at 29. In addition, between 1969 and 1974, the CAB granted less than four percent of all route applications. S. BREYER, supra note 4 , at 205.

58. The federal government has recognized this problem. The Airport and Airway Improvement Act of 1982, Pub. L. No. 97-248, $\$ 527,96$ Stat. 671, 698 (codified at 49 U.S.C.A. $\$ 2223$ (West Supp. 1983)), called for the creation of a task force "to study the problems of allocating the use of airport facilities and airspace (including, but not limited to, gate facilities, landing facilities, airspace slots, and ticketing and terminal space) among persons using or seeking to use such facilities." The task force was to study present methods of allocating the use of airport space and make recommendations for improving these methods. 49 U.S.C.A. § 2223(a) (West Supp. 1983). The Airport Access Task Force presented its report to Congress on March 10, 1982. See AIRPORT Access TASK ForcE, supra note 20 . One member of the task force, however, claimed that "our working group has failed adequately to address the question of how access to airports should be allocated." Id. at 41 .

59. A recent study shows that the prices of tickets to or from slot-constrained airports are higher than the prices of tickets for trips with similar costs involving airports that are not slot-constrained. See Graham, Kaplan \& Sibley, Efficiency and Competition in the Airline Industry, 14 BELL J. Econ. 118,134 (1983).

60. "Excess demand" is the difference between the quantity of a good demanded at a particular price and the quantity supplied at that price. When the quantity of a good demanded is greater than the amount supplied, the available supply must somehow be rationed among the consumers desiring to purchase the good. If the price of the good is not fised, a positive excess demand will tend to be eliminated by an increase in price, which will generally both increase the quantity supplied and decrease the quantity demanded. 
constrained airport will therefore be reflected in an unsatisfied demand for slots. Thus, both airlines and slot-constrained airports must ration their available capacity by some mechanism. But whereas the rationing of slots is done on a non-price basis, there is nothing to stop deregulated airlines from rationing their own services on the basis of price. The combination of airline deregulation without any change in existing airport regulation leads to a situation where the scarcity rents, ${ }^{61}$ which arise ultimately from limited airport capacity, accrue to the airlines that use slot-constrained airports rather than to the airports themselves. ${ }^{62}$

Thus, the current regulatory system for the allocation of slots simply provides an arena in which each airline fights to capture as much of these rents for itself as possible. ${ }^{63}$ This system is neither efficient nor equitable.

\section{Towards an Efficient Allocation System}

To be efficient, an allocation must maximize the net scarcity rents associated with the limited number of available slots. ${ }^{64}$ This is accomplished by allocating slots to the airlines that can sell tickets to the passengers who place the highest value, measured in terms of willingness to pay, on using

61. A "scarcity rent" is a payment for an input whose supply, at least in the short run, is fixed (and therefore "scarce"). A "rent" in general is any payment greater than the amount necessary to induce the supply of an input. Where the supply of an input is fixed, the price of the input will consist entirely of rent. See J. HirshLeIfER, supra note 19 , at 477-78. For a discussion of the relationship between scarcity rent and operating profit, see H. VARIAN, Microzconomic ANALysis 59-60 (1978).

62. An estimate of the magnitude of these scarcity rents was provided by the prices at which slots traded during the six weeks in 1982 when the FAA, in response to the PATCO strike, allowed the airlines to buy and sell slots from one another. Sep 47 Fed. Reg. 19,989 (1982) (notice of change in policy); see also supra note 55 (discussing FAA's response to PATCO strike). The reported per-slot prices ranged from \$12,000 to over \$500,000. See Koran \& Ogur, Airport Access Problems: Lessons Learned from Slot Regulation by the FAA 11 (May 1983) (FTC staff report).

63. This fight seems to be skewed in favor of new entrants:

Entry into the slot restricted airports has not been much of a problem for small carriers that desire only a few slots. The reason entrants have been able to obtain slots is that there appears to be a general belief that in the event of default [by the scheduling committee] each entrant will obtain some slots from the FAA. Because they expect that any administrative process will provide them with some slots, they can and do threaten to force the committee into default if their demands are not satisfied. Air carriers with an initially large share of slots have usually been unable to expand operations at the slot restricted airports, whereas airlines with small allocations have been able to expand their operations over time.

CAB ANTITRust REPORT, supra note 3, at 77; see also infra note 67 (airlines' bargaining positions influenced by expectations of FAA treatment). In addition, the FAA has followed a policy of giving preference to new entrants in the allocation of slots as the air traffic control system returns to normal following the air traffic controllers' strike in 1981. See 47 Fed. Reg. 7816 (1982) (outlining FAA procedures for allocating slots at airports adversely affected by strike). The apparent reason for this policy is a desire to foster competition in the airline industry. The problem with this policy, however, is that more competition does not always ensure economic efficiency. See infra pp. 329-31.

64. Net scarcity rents are the rents generated by a particular use of a resource minus the costs associated with that use; they are therefore simply a measure of net benefit. 
the slot-constrained airport. In practice, such airlines would be able to pay the most for the right to use an airport. ${ }^{65}$

The FAA's slot-allocation system, however, can reach an efficient result only by accident. ${ }^{66}$ The allocation of slots by a scheduling committee is a function of the relative bargaining positions of the various airlines seeking slots. ${ }^{67}$ Since the airlines with the strongest bargaining positions frequently are not those that place the highest value on the limited number of available slots, ${ }^{68}$ the resulting allocations are generally inefficient. Moreover, under the existing system, landing slots cannot be sold, ${ }^{68}$ even though these transactions would lead to a more efficient allocation of slots by transferring a particular slot to the airline able to earn the highest rent on the slot. ${ }^{70}$

Allowing the sale of slots would also promote dynamic economic efficiency. First, the prices at which landing slots traded would guide investment decisions concerning the construction of new airports to serve a particular region. Second, prices which reflected the true economic value of

65. The airline with the right to use a particular slot will presumably maximize the rent associated with that slot given its current route structure. A particular airline, however, may not possess the route structure that would generate the maximum amount of net scarcity rent. Determining which routes will maximize rents may require considerable effort by the airline. Moreover, attaining this maximum rent may require that an airline fly to or from an airport outside of its current network, and hence the airline will not have the necessary ground facilities. One would thus expect that the adjustment of an individual airline to an efficient use of a given number of slots would be a slow process.

66. This is particularly true of the FAA's use of a lottery to allocate additional slots at airports during the recovery from the PATCO strike. See supra note 55.

67. Since the FAA will impose an allocation if the scheduling committee fails to reach an agreement, each airline's bargaining position ultimately depends on the participants' expectations of the FAA allocation in the event that an agreement is not reached. Although an airline's historic use pattern undoubtedly gives it some bargaining power in the scheduling committee, the FAA has demonstrated that it will treat new entrants favorably, giving them a relatively strong bargaining position. See supra note 63.

68. In fact the systematic bias in favor of new entrants, see supra note 63 , probably works in the opposite direction. Because of their lack of experience in the industry, new entrants can generally be expected to have the least amount of information about the most efficient use of scarce slots.

69. See 47 Fed. Reg. 29,814 (1982) (announcing end of policy allowing slots to be sold). The FAA does allow slots to be traded under the auspices of the Air Transport Association (ATA), an industry trade group. See id. (outlining guidelines for slot trading). This, however, only enables exchange among airlines with an existing allocation of slots. Furthermore, before an airline can trade its slots, the ATA must locate another airline with suitable slots that it is willing to trade. For a general discussion of the inefficiency of barter exchange, see J. HiRSHLEIFER, supra note 19, at $250-53$.

70. If slots were sold, the prices at which they traded would convey information about the value placed on them by other airlines. An airline would enter a city-pair market requiring the use of a slot only if it were willing to pay the market price for a slot, presumably because it had market information which indicated that it could earn higher rents on the slot. This would guarantee an efficient allocation of existing slots. In the absence of such price signals, the airlines lack the information necessary to make socially optimal decisions in terms of using or selling a particular slot. Additionally, in the absence of a requirement to pay for slots, each airline has an incentive to get as many slots as possible, regardless of their value to other airlines. For a general discussion of the role of prices as transmitters of information about the relative scarcity of goods and resources, see Hayck, The Use of Knowledge in Societ), 35 AM. EcON. REV. 519 (1945). 
landing slots would encourage innovations shortening the time required to land or take off, and reducing the amount of noise that airplanes produce. ${ }^{71}$ Finally, the efficient pricing of slots would stimulate the development and use of larger planes, which would reduce the demand for slots. ${ }^{72}$

There are, however, equitable objections to granting airlines full property rights in the slots allocated to them. It is not clear, for example, why airlines should be allowed to capture the rents associated with scarce airport capacity by selling slots which they did not have to pay for in the first place. ${ }^{73}$ It therefore seems most appropriate to have a governmental body capture these scarcity rents because this disposition would spread the benefit of these rents among all taxpayers rather than just among the shareholders and employees of airlines. ${ }^{74}$

One possible solution to this problem is to allow slot-constrained airports to auction the available number of slots. ${ }^{75}$ The revenues from such

71. See supra note 46.

72. The mere existence of slot constraints may encourage the development of larger planes. If, however, some airlines are able to obtain as many slots as they desire while other airlines receive none, this stimulus will not be as strong as that provided by the efficient pricing of slots.

73. Nevertheless, when compared to the current system for allocating slots, this type of reform would only allow the airlines to do explicitly and efficiently what they now do implicitly and inefficiently (because slot rents are not maximized under the current allocation system). For some airlines, however, slot rents may properly be considered to be a return for bearing the risk associated with an airport's construction. See infra p. 334.

74. There are, however, equity and efficiency arguments against spreading the benefit of these scarcity rents on such a wide basis. The people who suffer most from the externalities inherent in the operation of an airport are those who live adjacent to the airport. Slot rents could be used to compensate these people through such mechanisms as property tax abatements.

Property values in such neighborhoods should reflect the costs of airport externalities. For example, studies of the effect of airport noise on property values have found reductions in property values ranging from 0.4 to 1.1 percent. See AIRPORT ACCESS TASK FoRCE, supra note 20, at 44. People who bought their homes after these costs became significant (roughly when the use of jet airplanes became prevalent) may, however, be compensated twice by such property tax abatements. In addition, some people, such as airline and airport employees, may actually prefer to live close to an airport despite the environmental costs of doing so. The equitable considerations for compensating people who prefer to live adjacent to an airport are not as strong as those for people who do not benefit from living close to an airport.

Limiting the spreading of slot rents could also increase economic efficiency. For example, if the binding constraint on an airport were the allowed amount of noise, slot rents could be used to "bribe" surrounding neighborhoods into relaxing this constraint.

75. An airport or the FAA could design such an auction in a number of ways. For example, the right to use a particular slot could be given either an infinite or a finite lifetime. In the former case, slot permits would be auctioned initially, but following this auction, sales and purchases of slots would be made solely in a secondary after-market. Such an after-market would have to be policed to insure that no one carrier used the permit market to establish a monopoly position at the airport. It is possible that such a monopolist would not use all of his slot permits in order to create an even greater scarcity of flights to and from the airport. For this reason, a system that involved an auction of slot permits with a finite lifetime may be preferable, since such a system would automatically destroy any accumulated market power periodically.

Even with periodically expiring slot permits, an active after-market should be encouraged. Without an after-market, the problem of allocating slots would have to be solved simultaneously for all slotconstrained airports in order to maximize the value of existing slots. For example, an airline might obtain a slot in the Washington National auction to initiate a particularly profitable service to Chicago's O'Hare Airport. Yet, subsequently, it may not be able to obtain a slot permit in the O'Hare 
auctions could be used for general governmental purposes, ${ }^{78}$ to compensate particular groups that bear most of the external costs from the operation of an airport, ${ }^{77}$ or to relax the particular constraint that is binding at a slot-constrained airport. ${ }^{78}$ Finally, the prices at which such permits traded would guide airport investment decisions as well as airline route decisions, promoting both efficient allocation and efficient production of slots.

Such auctions, however, would be subject to challenge both under the grant agreements under which airports receive federal construction subsidies $^{70}$ and under section 1513, which restricts the fees of all airports to a "reasonable" level. ${ }^{80}$ Thus, implementing this reform will most likely require that exceptions to these two provisions be made for slot-constrained airports, or that the term "reasonable" be redefined in a way that recognizes the need to allocate scarce landing slots through a market mechanism.

\section{Airport Terminal Gapacity Gonstraints}

Airline deregulation has exacerbated problems other than the inefficiencies and inequities of the current system of slot allocation. It has also shifted the effective power of approval over new air routes from the $\mathrm{CAB}$ to local airports and, in some cases, to incumbent airlines. Before deregulation, of course, the CAB had ultimate authority over all airline route decisions. ${ }^{81}$ Now that the $\mathrm{CAB}$ no longer has this authority, ${ }^{82}$ a crucial issue in initiating service at any airport, slot-constrained or not, is whether the airline can obtain adequate terminal facilities at the airport in question. Before an airline can use a particular route, it must have not only the right to take off or land at the relevant airports, but also access to

auction. Although the airline would undoubtedly use its National slot, by assumption it will be unable to use the slot in the most profitable way. Finding the optimal allocation of slots simultaneously for all slot-constrained airports, however, is an extraordinarily difficult, though arguably feasible, problem to solve. See Rassenti, Smith \& Bulfin, A Combinatorial Auction Mechanism for Airport Time Slot Allocation, 13 BeLl J. EcoN. 402 (1982).

The best type of market would appear to entail slot permits with a finite life with an initial airport auction and an after-market. In this case, staggering the expiration dates of slot permits would insure that a supply of permits would frequently appear on the market.

76. Since the federal government has subsidized the construction of public airports, see supra note 12 , it would probably claim at least a portion of these funds.

77. See supra note 74 .

78. For example, if the binding constraint on an airport were the amount of noise allowed, slot rents could be used to pay surrounding neighborhoods for relaxing this constraint. See supra note 74.

79. See supra p. 321. The amendment to 49 U.S.C. \$ 1718 (1976) (current version at 49 U.S.C.A. $\$ 2210$ (West Supp. 1983)), which was added by the Airport and Airway Improvement Act of 1982 , Pub. L. No. $97-248, \S 511,96$ Stat. 671,686 , is particularly relevant. The amendment requires that "all revenues generated by the airport, if it is a public airport, will be expended for the capital or operating costs of the airport . . ." 49 U.S.C.A. $\$ 2210(a)(12)$ (West Supp. 1983).

80. See supra p. 321.

81. See supra p. 320.

82. See supra p. 320. 
the airports' terminals to enplane and deplane passengers and to handle passengers' baggage. Since airports and airlines can use the power to control airport access as an effective barrier to entry into airline markets, ${ }^{83}$ local decisions concerning the allocation and expansion of airport terminal capacity have become much more significant in a deregulated airline industry because this protection from competition may give airlines the power to raise prices.

\section{A. The Allocation of Existing Terminal Capacity}

Since the deregulation of the airline industry, access to airports has been limited by the inability of some airlines to obtain space at airport terminals. ${ }^{84}$ Historically, most airports have leased space to airlines "on an exclusive basis for extended periods of time, usually 15 to 30 years." Because the incumbent airlines can generally refuse to sublease terminal space to other airlines, the incumbent airlines, rather than the airport, control access at airports where all terminal space has been leased. ${ }^{86}$ Thus the incumbent airlines will capture any scarcity rents arising from the fixed amount of terminal space.

This arrangement is arguably both equitable and efficient. The longterm lease agreements between the airlines and the airports not only facilitate the construction of airports, but also expose the airlines to the risk that the revenues generated by their use of the airport might be less than their required payments under the long-term lease. ${ }^{87}$ The scarcity rents

83. "A barrier to entry may be defined as a cost of producing (at some or every rate of output) which must be borne by a firm which seeks to enter an industry but is not borne by firms already in the industry." G. Stigler, The ORganization OF InDUSTRY 67 (1968). Where access to a particular type of facility, such as an airport, is absolutely essential to enter an industry, the power to deny access to the facility may create a barrier to entry by imposing on the potential entrant the necessity of bearing the full cost of providing the facility.

84. See AIRPORT ACCESS TASK FORCE, supra note 20, at 51-53. But see CAB ANTITRUST REPORT, supra note 3 , at 83 .

85. AIRPORT ACCESS TASK FORCE, supra note 20, at 57 . These leases have supported the construction financing of most major airports. Since 1960, most airports have funded construction by issuing revenue bonds. This type of bond is backed only by the revenue-generating potential of the facility being constructed. (General obligation bonds, by contrast, are backed by the taxing power of the issuer.) Long-term leases reduce the risks associated with revenue bonds by replacing the credit worthiness of the airport with that of the airlines obligated by the lease to make payments. "In return for making these commitments, tenant carriers were given substantial influence over the use of the facilities ... [including] exclusive rights to the facilities they lease." CAB ANTITRUST REPORT, supra note 3 , at 81 .

86. Sep AIRPORT Access TASK Force, supra note 20, at 63. A recent survey of the top 100 airports in the United States indicated that 60 of 88 responding airports do not have any unleased terminal space available for potential entrants. Of these 60,31 indicated that "subleasing did not appear to be an adequate solution because of the high existing utilization of leased space and facilities by the incumbent airlines or because current airlines would charge excessive rates to new sublessee airlines." Id. at 53.

87. In fact, the long-term lease agreements may be viewed as a form of vertical integration between an airport and the incumbent airlines. 
arising from the fixed amount of terminal space, or at least some part of them, may therefore be considered a return for bearing this risk. ${ }^{88}$ Moreover, the incumbent airlines, presumably, are profit maximizers who, in the absence of any monopoly power, will sublease their terminal space to the airlines that place the highest value on that space. This is, of course, the efficient allocation of the fixed amount of terminal space.

Economic inefficiencies will arise, however, if the incumbent airlines use their long-term leases to capture monopoly profits rather than scarcity rents. Monopoly profits would occur if incumbent airlines used their control over terminal access to create a barrier to the entry of potential competitors and thereby restrict output below the level of full utilization of the available amount of terminal space. To prevent such an inefficient exercise of monopoly power, airline terminal leasing practices-particularly refusing to lease underutilized space ${ }^{89}$ or requiring sublessees not to compete with the incumbent airline-should be subjected to a heightened antitrust scrutiny. ${ }^{90}$ Such scrutiny would encourage the full utilization of scarce terminal space. If all terminal space must be fully utilized, the airlines that control access to these facilities have an incentive to allocate access in the most efficient way.

\section{B. The Construction of New Terminal Capacity}

It may be possible at some airports to accommodate new entrants through the construction of additional terminal capacity. The incumbent airlines, however, will resist such expansion for several reasons: (1) the expansion of terminal capacity will reduce the scarcity value of existing

88. A similar argument could be made to support giving the airlines who helped finance the construction of airports which are now slot-constrained full property rights in the fixed number of available slots.

89. There have been reported cases of refusals to lease vacant space. See AIRPORT Access TASK ForCE, supra note 20, at 52 . Instead of asserting an outright refusal to lease terminal space, an incumbent airline may simply set unrealistic terms as a condition for leasing space. See $i d$. Although this may raise difficult factual issues, such demands should be treated as absolute refusals to deal.

90. A refusal to sublease underutilized space by an airline with a long-term lease for terminal space could be attacked under the "essential facility" doctrine of antitrust law. See United States v. Terminal R.R. Ass'n, 224 U.S. 383 (1912) (railroad's jointly owned corporation, which had obtained control over only feasible means of access to St. Louis, must provide access to non-proprietary competitors on reasonable and nondiscriminatory terms); L. Sullivan, ANTrTrust 126 (1977). A facility may be deemed essential "if duplication of the facility would be economically infeasible and if denial of its use inflicts a severe handicap on potential market entrants." Hecht v. Pro-Football, Inc., 570 F.2d 982, 992 (D.C. Cir. 1977), cert. denied, 436 U.S. 956 (1978).

The application of the essential facility doctrine has been limited to those facilities that can be shared without interfering with current users. Otter Tail Power Co. v. United States, 410 U.S. 366, 381 (1973) (utility cannot be ordered to interconnect with other electricity producers if interconnection impairs its capacity to serve its own customers); Hecht v. Pro-Football, Inc., 570 F.2d 982, 992-93 (D.C. Cir. 1977) (access to stadium cannot be ordered if access interferes with current tenant's use), cert. denied, 436 U.S. 956 (1978); L. SullivaN, supra, at 127-28. Thus, if an airline were to use all its leased terminal space, it would not be subject to antitrust attack. 
terminal space; (2) new entrant airlines might compete directly with incumbent airlines, reducing any monopoly power that the incumbents may have over airline routes; and (3) the construction of new terminal capacity may increase the rental rates or landing fees charged to incumbent airlines. ${ }^{91}$

There are several ways in which incumbent airlines might stop an airport's expansion. First, any airport seeking federal construction subsidies must "undertake reasonable consultations with affected parties using the airport at which such project is proposed."92 The incumbent airlines may be able to use these consultations to inhibit an airport's expansion. ${ }^{93}$ In addition, many airport leases contain clauses which require the approval of a "majority-in-interest" undertake certain projects. ${ }^{95}$ Since majority-in-interest clauses were included in airport terminal leases to protect airlines from unnecessary and extravagant expenditures by airport operators, the scope of issues covered by these clauses generally includes capital improvements or expansions and additional issues of debt. ${ }^{98}$ Such clauses thus give the incumbent airlines the power to veto the airport's expansion. ${ }^{97}$

Finally, incumbent airlines may be able to stop an airport's expansion through the federal statute-section 1513-that restricts airport fees to a "reasonable" level..$^{98}$ When a county or municipality decides to expand its airport, it must generally issue bonds to finance the project. ${ }^{98}$ Since the

91. Under the lease agreements at many airports, the cost of building new capacity is distributed over the entire terminal facility through a policy of "equalized rental rates." See ArRPORT Access TASK FORCE, supra note 20 , at 66 . When the cost of additional terminal capacity is increasing, the construction of new space will increase the average cost of all terminal space, and hence increase airport rental rates. "Recently, however, it has been suggested by some that this practice be revised and the cost of any new space be borne by those that occupy that space, usually a new carrier." Id. The Airport Access Task Force concluded, however, that such a "differential pricing" scheme "might impose a burden on new carriers [and] could be construed as anti-competitive." Id. at 67. Bul see infra p. 337 (equalized rental rates create excessive entry).

92. Airport and Airway Development Act of 1982, Pub. L. No. 97-248, § 511(c), 96 Stat. 671, 688 (codified at 49 U.S.C.A. $\$ 2210$ (c) (West Supp. 1983)) (former version codified at 49 U.S.C. $\$$ 1718(b) (1976)). The purpose of the requirement is to hold down the operating costs of incumbent airlines. See AIRPORT ACCESS TASK FORCE, supra note 20, at 57.

93. See AIRPORT Access TAsk Force, supra note 20, at 57. The Airport Access Task Force recommended that an analysis of the anticompetitive impact of the consultation requirement, which predates deregulation, be undertaken. See id. at 77.

94. The "majority-in-interest" is usually defined in terms of a specified percentage of enplanements or operations. See id. at 59.

95. - See id. at 59-60.

96. Sep id. at 60.

97. The Airport Access Task Force recommended that majority-in-interest clauses be eliminated or rewritten to reduce their anticompetitive impact. Id. at 61 .

98. 49 U.S.C. $\S 1513$ (b) (1976); see supra note 17. The airlines could also proceed on the theory that airport fees are an unconstitutional burden on interstate commerce in violation of the commerce clause of the Constitution. U.S. ConsT. art. I, § 8, cl. 3; see American Airlines v. Massachusetts Port Auth., 560 F.2d 1036 (1st Cir. 1977).

99. An airport may alternatively attempt to finance an expansion project by collecting higher fees 
issuance of new bonds increases the total debt of the airport, the airport must usually raise its landing fees and rental rates to make debt service payments. The airlines with existing facilities at the airport can jointly refuse to pay the higher fees and bring suit ${ }^{100}$ to have the fees declared unreasonable. ${ }^{101}$ These actions would effectively halt the planned bond issue by imperiling the funds for future debt service payments. ${ }^{102}$

Such concerted actions by airlines to monopolize the market for terminal facilities inflict injury on a direct competitor ${ }^{\mathbf{1 0 3}}$ and would therefore seem to violate both sections one and two of the Sherman Act. ${ }^{104}$ The airlines, however, can probably successfully claim immunity from the antitrust laws under the Noerr-Pennington doctrine, a First Amendmentbased immunity to the antitrust laws designed to protect a business's right to influence government action. ${ }^{105}$ Although no court has yet ruled on this

than are necessary to meet current costs. See Indianapolis Airport Auth. v. American Airlines, 17 Av. Cas. (CCH) I 17,513 (S.D. Ind. Sept. 30, 1982).

100. Although $\S 1513$ does not explicitly grant airlines a right of action, the courts have assumed such a right exists without comment. See supra note 33 .

101. The incumbent airlines could argue that higher rental rates and landing fees based on the construction costs of new capacity which they will not use are unreasonable, since such charges are greater than the charges necessary to defray the capital and operating costs of their own facilities. See Evansville-Vanderburgh Airport Auth. v. Delta Airlines, 405 U.S. 707, 719 (1973) (fees must not be "excessive in relation to costs incurred by the taxing authorities"). The airport, however, could argue that the increased demand for terminal space and the increased cost of providing terminal space have increased the value of the "governmental benefit conferred," and therefore, that the higher fees are not excessive or unreasonable. See id. at 716-17 (fee not "excessive in comparison with the governmental benefit conferred . . . will pass constitutional muster").

102. This was exactly the effect of a pending suit brought by the airlines with existing facilities against Broward County Airport in Florida. Eastern Air Lines v. Broward County, No. 82-6031-CivNCR (S.D. Fla. 1982).

103. The airlines and the airport may be viewed as direct competitors here because the airlines can lease the use of their ground facilities to other airlines; hence, both the airport and the airlines are potential suppliers of these services.

104. Section 1 of the Sherman Act prohibits "[e]very contract, combination in the form of trust or otherwise, or conspiracy, in restraint of trade or commerce . . ." 15 U.S.C. \$ 1 (1976). Section 2 prohibits any "attempt to monopolize . . . any part of the trade or commerce among the several States ...."Id. \& 2.

105. See United Mine Workers v. Pennington, 381 U.S. 657 (1965); Eastern R.R. Presidents Conference v. Noerr Motor Freight, 365 U.S. 127 (1961). The Supreme Court later extended NoerrPennington protection to litigation before courts and administrative agencies. California Motor Transport Co. v. Trucking Unlimited, 404 U.S. 508 (1972). Although the Court has established a "sham" exception to the doctrine where the attempt to influence governmental action is merely a part of a larger overall scheme to restrain trade, Noerr, 365 U.S. at 144, it is unlikely that the sham exception would be applied to this type of suit brought by the airlines. First, it is unclear whether a single suit by the alleged violator is sufficient to meet the requirements of the sham exception. Compare Vendo Co. v. Lektro-Vendo Corp., 433 U.S. 623, 643-45, 652-54 (1977) (two Justices concurring with plurality opinion on the grounds that a single suit could not establish the sham exception, and four Justices dissenting on the grounds that a single suit is sufficient to state a cause of action under the sham exception) and Central Bank v. Clayton Bank, 424 F. Supp. 163, 167 (E.D. Mo. 1976) (requiring multiple, repetitive suits to establish sham exception), aff'd mem., 553 F.2d 102 (8th Cir.), cert. denied, 433 U.S. 910 (1977) with Clipper Exxpress v. Rocky Mountain Motor Tariff Bureau, 690 F.2d 1240, 1254-57 (9th Cir. 1982) (single suit sufficient to establish sham exception), cert. denied, 103 S. Ct. 1234 (1983). Second, the airports must also show that the airlines' suit was simply an effort to interfere with a competitor, rather than a genuine petitioning activity. Since the 
issue, if the courts do grant Noerr-Pennington immunity to airlines in such rate challenges, the airlines could deter entry into certain city-pair markets without the risk of antitrust liability.

As these possibilities illustrate, the airlines with existing long-term leases for terminal space have significant control over decisions to expand airport capacity. This authority had no potentially significant anticompetitive effects during the era of $\mathrm{GAB}$ regulation because the $\mathrm{GAB}$ controlled all entry and rate decisions in the airline industry. ${ }^{108}$ With the deregulation of the airline industry, however, these various methods of preventing airport expansion can have a significant anti-competitive impact because they enable incumbent airlines to block the entry of new competitors. Since the power to stop an airport's expansion can be a very effective barrier to entry, ${ }^{107}$ it should not be wielded by the incumbent airlines in a deregulated industry.

Who should decide when entry ought to be accommodated through the construction of new terminal capacity? And how should the costs incident to an airport's expansion be distributed among new and old users?

Attaining an optimal amount of entry requires that new entrants pay the full cost of their entry. If new entrants pay less than this amount, shifting part of the cost of expansion onto incumbent airlines, there will be too much entry. ${ }^{108}$ At most airports, such cost externalization occurs through the policy of "equalized rental rates," in which the cost of new capacity is distributed over the entire terminal facility so that all tenants pay the same rental rate regardless of whether they are an old or new tenant. ${ }^{109}$ When the marginal cost of new capacity is greater than the average cost of existing capacity, an equalized rental policy implies that incumbent airlines will "subsidize" entry by paying higher, post-entry rental rates, and conversely, that new entrants will not pay the full cost of their entry. Thus, to attain the correct degree of entry, capacity expansion decisions should be placed with new entrants, but at the same time, the new entrants should be required to pay the full cost of their entry. ${ }^{110}$

airlines can argue that their suit is designed to prevent "unreasonable" fees from being imposed on them, it seems very unlikely that the airport could meet the burden of proof required to establish a sham exception in a case involving only one lawsuit.

106. See supra p. 320.

107. See supra note 83 .

108. This cost shift is called "cost externalization." Cost externalization leads to excessive entry and airport expansion because entrants do not pay the full social cost of their entry when deciding whether to enter. For a more general discussion of externalities and their effect on production or consumption decisions, see J. HIRSHLEIFER, supra note 19, at 532-34.

109. See supra note 91 .

110. This rule will, of course, require a system of differential pricing whereby new entrants are placed at a cost disadvantage relative to incumbents. The apparent harshness and anticompetitive effects of this rule, however, are mitigated by two factors. First, to the extent that scarcity rents compensate incumbent airlines for the risks incurred through their commitments on long-term leases, 


\section{CoNCLUSION}

The mobility of capital in the airline industry suggests that airline markets should perform efficiently even at relatively high levels of concentration because the threat of entry should keep fares at competitive levels, particularly since exit from the airline industry is relatively easy. ${ }^{111}$ In fact, the "contestability" of airline markets is the strongest theoretical argument in favor of airline deregulation. ${ }^{112}$ If, however, the threat of entry is to provide sufficient pressure to keep airline prices at competitive levels, potential competitors must have access to the airports necessary to serve a particular route. Thus, in a deregulated airline industry, there must be much greater reliance on airports to ensure competitive performance of the industry.

The GAB is certainly aware of this general problem, ${ }^{113}$ and the FAA's treatment of new entrants at slot-constrained airports exhibits a similar concern for promoting ease of entry into airline markets. Unfortunately, simply employing this general concern for guaranteeing airport access within the pre-existing system of slot allocation has only exacerbated the economic inefficiencies associated with slot allocation. Allocating slots at slot-constrained airports efficiently requires abandoning the current nonprice rationing system and adopting a system that relies on prices.

Finally, the CAB has been concerned primarily with airport access restraints imposed by airport operators rather than with access restraints created by airlines. ${ }^{114}$ Although the actions of airport operators are a cause for concern in certain situations, airlines with existing landing

see supra pp. 333-34, this rule works to preserve this legitimate return to incumbent airlines. Second, new entrants into the airline industry are often non-union, anomalously making new entrants the least-cost producers. See Graham, Kaplan \& Sibley, supra note 59, at 136 . The lower labor costs tend to offset the barrier to entry created by higher airport-access costs.

111. The threat of entry (or "potential competition") encourages competitive pricing because incumbent firms know that if they charge a greater than competitive price, new firms will be attracted into the market, driving prices down to competitive levels. Easy exit from a market encourages entry because a potential entrant will be less hesitant about entering a market if he need not fear retaliatory behavior by incumbents and if the costs of entry are easily recoverable. Exit from markets in the airline industry is relatively easy because the major portion of a firm's capital (aircraft) can be shifted very quickly to other markets. See Bailey \& Panzar, The Contestability of Airline Markets During the Transition to Deregulation, 44 LAW \& ConTEMP. ProBs. 125, 128-29 (1981). In addition, there is a good market for used aircraft.

112. See id. But see Graham, Kaplan \& Sibley, supra note 59, at 135 (airline fares per mile related to market concentration).

113. See CAB ANTtTRUST REPORT, supra note 3, at 167-84 (discussing antitrust problems created by airport operators restraining access to their airports). This increased reliance on airports creates a great strain in the traditional relationship between the federal government and airports. See supra note 13.

114. See CAB ANTITRust Report, supra note 3, at 167-84. The CAB has also expressed concern that long-term lease agreements between airlines and airports may represent an entry barrier to particular city-pair markets, but concludes that "groundside access has not yet reached the point where it can be considered an important entry barrier." Id. at 83. But sep AIRPORT AccESS TASK ForCE, supra note 20, at 51-53. 
rights may be able to use their advantageous positions as incumbents, which were created during the era of $C A B$ regulation, to impose access constraints at some airports. Moreover, in some cases airlines may be able to use their power to block entry but remain immune from attack under the antitrust laws. If the full benefits of airline deregulation are to be obtained, the rights, powers, and responsibilities of airport proprietors, incumbent airlines, and new entrant airlines must be redefined to take account of the changes that deregulation introduced into the airline industry. 